\title{
Sister chromatid exchanges in rat pleural mesothelial cells treated with crocidolite, attapulgite, or benzo 3-4 pyrene
}

\author{
SOPHIE ACHARD, MYLENE PERDERISET, MARIE-CLAUDE JAURAND \\ From INSERM U 139 and CNRS UA 604, CHU Henri Mondor, 94010, Créteil Cedex, France
}

Sister chromatid exchange (SCE) quantitation is a sensitive test with which to detect the effects of mutagens and has been used to determine the clastogenic potency of materials such as mineral fibres. $^{1-4}$ Attapulgite fibres are used for many different industrial purposes and their carcinogenic potency needs to be evaluated but until now few data have been available. Pott et al found that palykorskite fibres were carcinogenic in rats ${ }^{5}$ and Wagner reported that attapulgite from Spain induced mesotheliomas when injected into the pleural cavity of Fischer 344 rats $^{6}$; short attapulgite fibres did not increase the incidence of tumours. ${ }^{7}$

The aim of the present work was to test the in vitro effect of attapulgite on SCE induction. Since pleural mesothelial cells are target cells in fibre related diseases, the test was performed on rat cell cultures and the effects were compared with those obtained with crocidolite fibres. In addition, benzo 3-4 pyrene (BP) was used to assess the reactivity of mesothelial cells to a known mutagen.

\section{Material and methods}

\section{PARTICLES AND CHEMICALS}

A sample of attapulgite was obtained from Senegal bed. Electron microscopic studies showed that the particles had a fibrous shape with a length less than $2 \mu \mathrm{m}$. Crocidolite was obtained from the Union Internationale contre le Cancer, BP was supplied by Sigma, and dimethyl sulphoxide (DMSO) by Merck. The particles were suspended in culture medium $(200 \mu \mathrm{g} / \mathrm{ml})$ and dispersed by sonication for 10 minutes $(20 \mathrm{kHz}, 20 \mathrm{w})$. BP was solubilised in DMSO or in acetone.

\section{CELLS}

Rat pleural mesothelial cells (RPMC) were cultured as described elsewhere. ${ }^{8}$ Briefly, RPMC was grown at $37^{\circ} \mathrm{C}$ in Ham F10 supplemented with $10 \%$ fetal calf serum, cysteine $200 \mu \mathrm{g} / \mathrm{ml}$, vitamin $\mathrm{C} 50 \mu \mathrm{g} / \mathrm{ml}$, glutamine $233 \mu \mathrm{g} / \mathrm{ml}$, penicillin $100 \mathrm{units} / \mathrm{ml}$, and streptomycin $50 \mu \mathrm{g} / \mathrm{ml}$. The $\mathrm{pH}$ was adjusted with $1 \%$ HEPES. Secondary cultures were used; the cells were between the 12th and 15th passage (about 20-25 doublings).

RPMC were routinely passaged using a trypsinisation procedure. Twenty four hours after trypsinisation RPMC were treated with different concentrations of fibres $(10,15$, and $20 \mu \mathrm{g} / \mathrm{ml})$ for 48 hours or with $0.5 \mu \mathrm{g} / \mathrm{ml}$ BP solubilised either in DMSO or in acetone, for different periods; the final DMSO and acetone concentration were $0 \cdot 1 \%$. RPMC were then treated with $10 \mu \mathrm{g} / \mathrm{ml}$ of 5-bromodeoxyuridine (BrdUrd) for 70 hours corresponding to about two cell cycles.

\section{Chromosome preparation and staining}

Colcemid (final concentration $0.33 \mu \mathrm{g} / \mathrm{ml}$ ) was added during the final 90 minutes of incubation. Mitotic cells were collected by mild trypsinisation, centrifuged $(15 \mathrm{~min}, 300 \times \mathrm{g})$, and treated at $37^{\circ} \mathrm{C}$ with $0.075 \mathrm{M}$ hypotonic $\mathrm{KCl}$ for 30 minutes. Cells were fixed twice in methanol: glacial acetic acid $(3: 1)$ at $+4^{\circ} \mathrm{C}$. Spreading and staining were performed according to the method of Dutrillaux and Couturier. ${ }^{9}$ Slides were stained with Hoechst $33258(5 \mu \mathrm{g} / \mathrm{ml})$, exposed to a germicide lamp in $0.1 \mathrm{M}$ phosphate buffer, $\mathrm{pH} 6.8$ for two hours, and incubated in $2 \times$ super concentrated solution $(0.3 \mathrm{M}$ sodium chloride $0.03 \mathrm{M}$ trisodium citrate) at $60^{\circ} \mathrm{C}$ for 30 minutes. Cells were stained with $3 \%$ Giemsa.

\section{Scoring and statistical analyses}

Thirty metaphases having 38-42 chromosomes per metaphase were scored. The results were expressed as number of SCEs per metaphase. The Mann-Whitney test was used to compare the data obtained with untreated and treated cultures and the effect of dose or time of exposure to the particles or chemicals. 
Table 1 Percentage of metaphases in a given cell cycle according to period of incubation

\begin{tabular}{|c|c|c|c|c|}
\hline & \multicolumn{4}{|c|}{ Time of incubation with BrdU (hours) } \\
\hline & 50 & 64 & 67 & 72 \\
\hline $\begin{array}{l}\text { 1st cell cycle } \\
\text { 2nd cell cycle } \\
\text { 3rd cell cycle }\end{array}$ & $\begin{array}{r}90 \\
10 \\
0\end{array}$ & $\begin{array}{r}26 \\
68 \\
4\end{array}$ & $\begin{array}{l}12 \\
78 \\
10\end{array}$ & $\begin{array}{r}2 \\
85 \\
13\end{array}$ \\
\hline
\end{tabular}

100 metaphases were analysed for each incubation time.

\section{Results}

To obtain a maximal number of metaphases from cells having performed two cell cycles the frequency of these metaphases were determined according to the period of incubation with BrdU. Table 1 shows that the maximum number was obtained at 72 hours. A period of 70 hours was retained for the present experiments.

Attapulgite did not induce SCEs. Table 2 shows that no significant increase in the number of SCEs per metaphase was obtained with 10 or $20 \mu \mathrm{g} / \mathrm{ml}$. Crocidolite fibres were potent in increasing the number of SCEs per metaphase, which was significantly enhanced at all experimental doses.
Achard, Perderiset, Jaurand

After treatment with BP a significant increase in SCEs was obtained whatever the solvent, DMSO, or: acetone (table 3). The SCE level increased with time; $\Rightarrow$ this effect was stronger at the beginning of the experiment and was more or less stationary after 20 hours.

It should be noted that $0.1 \%$ DMSO slightly을 increased the number of SCEs per metaphase, but the $\frac{\bar{s}}{\frac{1}{6}}$ difference when compared with untreated controls $\stackrel{\varnothing}{\propto}$ was not significant, except after five hours in oneo experiment. Acetone $0 \cdot 1 \%$ also increased SCEs and ${ }^{\text {s }}$ the difference was significant at 48 hours. The effect of ${ }^{\circ}$ BP solubilised in acetone was higher than when solu- $\overrightarrow{\vec{\omega}}$ bilised in DMSO.

\section{Discussion}

To our knowledge the cytogenetic effects of attapulgite have not been published. Recently N $_{\infty}$ Denizeau $e t$ al reported negative results when testing $\vec{\rho}$ for unscheduled DNA synthesis by attapulgite fibres on hepatocytes. ${ }^{10}$ Our data indicate that attapulgite $\rightarrow$ did not induce SCEs in cultured RPMC; this was not $\frac{D}{0}$ due to a lack of fibre ingestion because intracellular fibres were seen on sections observed with electron $\vec{\omega}$ microscopy. According to our results, crocidolite con- $-\stackrel{\infty}{-}$ trasted with attapulgite; indeed $10 \mu \mathrm{g} / \mathrm{ml}$ of cro- $\square$ cidolite fibres increased the level of SCEs by about

Table 2 SCE induction by minerals

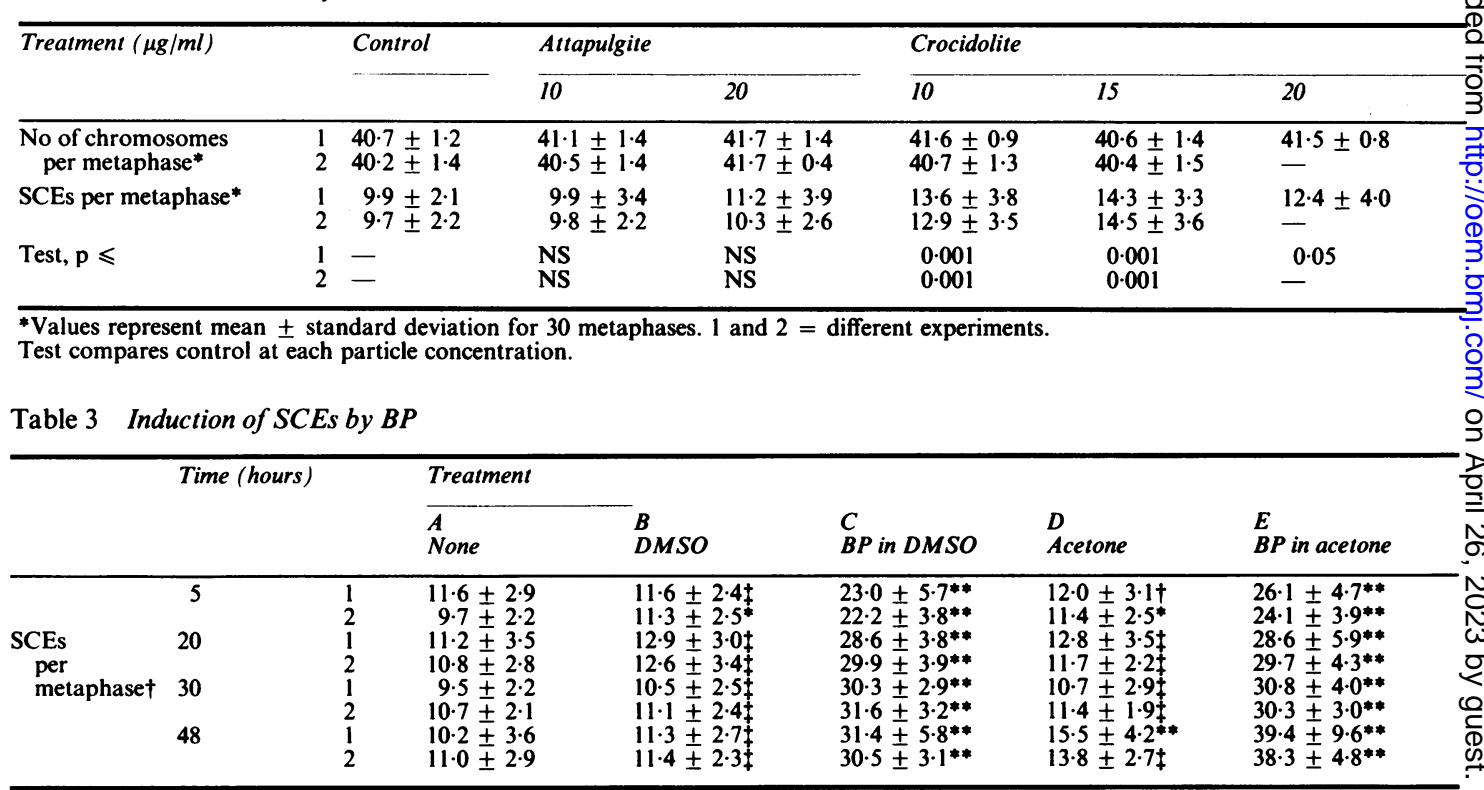

Test: comparison between DMSO/BP in DMSO, acetone/BP in acetone, none/DMSO, or none/acetone.

${ }^{*} \mathrm{p} \leqslant 0.01 ;{ }^{* *} \mathrm{p} \leqslant 0.001$.

+ Values represent mean \pm standard error for 30 metaphases.

$\ddagger$ Not significant.

1 and 2 = Two different experiments. 
$30 \%$ and by $40 \%$ in a concentration of $15 \mu \mathrm{g} / \mathrm{ml}$. In previous experiments chrysotile fibres also enhanced the number of SCEs. ${ }^{11}$ The lower effect with $20 \mu \mathrm{g} / \mathrm{ml}$ of crocidolite fibres could be related to a cytotoxicity. Indeed, the basis of the SCE method consisted in the observation of metaphase cells; it is possible that the cells having a high SCE level are killed or strongly injured cells and are then not detected. Similar results have been obtained when chromosomal aberrations were determined in chrysotile treated $\mathrm{RPMC}^{12}$; in these experiments low doses induced a dose dependent increase in abnormal metaphases whereas higher concentrations resulted in several abnormal metaphases similar to the number obtained with the control. Conflicting data have been obtained with crocidolite fibres since Casey ${ }^{3}$ and Price-Jones et $\mathrm{al}^{2}$ did not find SCEs increased in V 79-4 or CHO-K1. By contrast, Livingston et al observed a significantly raised SCE rate in medium and larger chromosomes of $\mathrm{CHO}$ cells. ${ }^{1}$ These discrepancies could be related to the different nature of the cells and also to the methodology. Price-Jones et al used an experimental procedure different from the one described in the present paper since the dusts were added while the cells were in suspension. ${ }^{2}$ In our experiments RPMC were firstly plated and then dust treated before their exposure to BrdU and arrest in metaphase; this was done to assess the unrepaired remaining DNA lesions.

BP was more potent than crocidolite fibres in inducing SCEs. For example, after 30 hours of incubation SCEs were enhanced by $300 \%$ whereas SCEs enhancement did not exceed $48 \%$ after treatment with crocidolite. It should be noted that acetone induced a slight increase in SCEs after 48 hours of incubation. This was not observed with DMSO and suggests that the stronger effect of BP solubilised in acetone when compared with DMSO could be due to a synergism between acetone and BP. The results obtained with BP indicate that cultured RPMC synthetise BP metabolites which interact with DNA. This is in agreement with a previous study showing that RPMC are able to metabolise $\mathrm{BP}^{\mathbf{1}}$; RPMC may be a useful model to study the chromosomal effects of chemicals.

\section{Conclusion}

This attapulgite sample did not induce SCE in cultured RPMC but crocidolite fibres produced SCEs. If the SCE technique is taken as an indicator of a carcinogenic potency these results do not disagree with animal data because the attapulgite sample used in this experiment contained short fibres by contrast with the paly-gorskite or Spanish attapulgite used by Pott $e t a l^{5}$ and Wagner ${ }^{6}$ respectively in their animal experiments. According to Stanton's hypothesis these short fibres would not be carcinogenic. ${ }^{14}$ Concerning crocidolite fibres, their positive effect is in agreement with their well known carcinogenicity in animals. ${ }^{1516}$

This work was supported by INSERM and CNRS funds. We thank Rhône Poulenc for the attapulgite fibres and Laurence Kheuang, Annie Renier, and Laure Magne for their help.

\section{References}

1 Livingston GK, Rom WN, Morris MV. Asbestos induced sister chromatid exchanges in cultured Chinese hamster ovarian fibroblast cells. $J$ Environ Pathol Toxicol 1980;4:373-82.

2 Price-Jones MJ, Gubbings G, Chamberlain M. The genetic effects of crocidolite asbestos; comparison of chromosome abnormalities and sister-chromatid exchanges. Mutat Res 1980;79: $331-6$.

3 Casey G, Sister chromatid exchange and cell kinetics in CHO-K I cells, human fibroblasts and lymphoblastoid cells exposed in vitro to asbestos and glass fibers. Mutat Res 1983;116:369-77.

4 Tice RR, Lambert B, Morimoto K, Hollaender R. A review of the international symposium on sister chromatid exchanges: twenty five years of experimental research. Environ Mutagen 1984;6:737-52.

5 Pott F, Dolgner R. Friedrichs KH, Huth F. Effect oncogène des poussières fibreuses: l'expérimentation animale et des relations avec la carcinogénèse humaine. Annals of Anatomical Pathology 1976;21:237-46.

6 Wagner JC. Compte rendu du symposium mondial sur l'amiante. Montréal, Canada, 25-27 Mai, 1982. Montreal: Canadian Asbestos Information Center, 1982:263-86.

7 Lipkin LE. Failure of attapulgite to produce tumors prediction of this result by in vitro cytotoxicity test. In: Beck EG, Bignon J, eds. In vitro effiects of mineral dusts. Vol 3. (NATO ASI Series. Series G: ecological systems.) 1985:539-42.

8 Jaurand MC, Bernaudin JF, Renier A, Kaplan H, Bignon J. Rat pleural mesothelial cells in culture. In vitro 1981;17:98-106.

9 Dutrillaux B. Couturier J. La pratique de l'analyse chromosomique. Paris: Masson, 1981. (Technique de Laboratoire No 12.)

10 Denizeau F, Marion M, Chevalier G, Cote MG. Absence of genotoxic effects of non asbestos fibres. Cell Biology and Toxicology 1985;1:23-32.

11 Jaurand MC, Bastie-Sigeac I, Paterour MJ, Renier A, Bignon J. Possibility of using rat mesothelial cells in culture to test cytotoxicity, elastogenicity and carcinogenicity of asbestos fibers. Ann NY Acad Sci 1983;407:409-1.

12 Jaurand MC, Kheuang L, Magne L, Bignon L. Chromosomal changes induced by chrysotile fibers or benzo 3-4 pyrene in rat pleural mesothelial cells. Mutat Res 1986;169:141-8.

13 Bastie-Sigeac I, Hubert-Habart M, Jaurand MC, Bignon J. Metabolisme du Benzo(a)pyrène par des cellules mésothéliales pleurales de rat en culture. Comptes Rendus de l'Académie des Sciences 1984;298:423-6.

14 Stanton MF, Layard M, Tegeris A, Miller E, May M, Kent E. Carcinogenicity of fibrous glass: pleural response in the rat in relation to fiber dimension. $J$ Natl Cancer Inst 1977;58:587-603.

15 Wagner JC, Berry G. Mesotheliomas in rats following inoculation with asbestos. Br J Cancer 1969;23:567-81.

16 Monchaux G, Bignon J, Jaurand MC, et al. Mesothelioma in rats following inoculation with acid leached chrysotile asbestos and other mineral fibres. Carcinogenesis 1981;2:229-36. 